\title{
Plasma visfatin concentrations in hypothyroid patients and its relationship with thyroid autoimmunity and atherosclerosis
}

\author{
Hipotiroid hastalarda plazma visfatin konsantrasyonlarının tiroid otoimmünitesi \\ ve ateroskleroz ile ilişkisi
}

\author{
Bekir Uçan ${ }^{1}$, Nur Kebapçı², Sema Uslu³ ${ }^{3}$ Mehmet Kara ${ }^{3}$, Nevbahar Akçar Değirmenci ${ }^{4}$, Setenay Öner ${ }^{5}$ \\ ${ }^{1}$ Department of Endocrinology and Metabolism, University of Health Sciences, Dışkapı Y1ldırım Beyazıt Training and \\ Research Hospital, Ankara, Turkey \\ ${ }^{2}$ Department of Endocrinology and Metabolism, Osmangazi University Medical Faculty, Eskişehir, Turkey \\ ${ }^{3}$ Department of Biochemistry, Osmangazi University Medical Faculty, Eskişehir, Turkey \\ ${ }^{4}$ Department of Radiology, Osmangazi University Medical Faculty, Eskişehir, Turkey \\ ${ }^{5}$ Department of Biostatistics, Osmangazi University Medical Faculty, Eskişehir, Turkey
}

Received: 10.12.2017 Accepted: 26.01.2018 Doi: 10.21601/ortadogutipdergisi.364345

\begin{abstract}
Aim: Visfatin/pre-B cell enhancement factor stimulates the production of inflammatory cytokines released from adipose tissue such as TNF- $\alpha$ and IL-6, which are shown to be related to the pathogenesis of insulin resistance, diabetes, dyslipidemia, inflammation, autoimmune diseases, and atherosclerosis. Our aim was to evaluate plasma visfatin concentrations in patients with autoimmune hypothyroidism and its relationship with thyroid autoimmunity and atherosclerosis.
\end{abstract}

Material and Method: Thirty-five patients with newly diagnosed Hashimoto's thyroiditis (32 women/3 men, mean age $43.8 \pm 9.6$ years) and 18 healthy controls (17 women/ 1 men, mean age $43.3 \pm 5.2$ years) were enrolled in the study. Anthropometric measurements, carotid intima-media thickness (CIMT), serum anti-Tg, anti-TPO, hsCRP, homocysteine, lipo(a), ApoA, ApoB1, $\beta$-2 microglobulin, insulin, glucose, visfatin, IL6, TNF- $\alpha$, oxidized-LDL concentrations, lymphocyte subgroups and lipid profile were investigated both before and after thyroid hormone replacement therapy. Serum visfatin concentrations were determined by enzyme-linked immunosorbent assay (ELISA).

Results: Mean serum visfatin concentrations were similar between autoimmune hypothyroidism group and control group $(6.29 \pm 1.63 \mathrm{ng} / \mathrm{ml}$ to $6.36 \pm 1.51 \mathrm{ng} / \mathrm{ml}, \mathrm{p}>0.05)$ and it was not correlated with thyroid autoimmunity and atherosclerosis markers. Plasma visfatin, oxidized LDL, IL-6, and TNF- $\alpha$ concentrations did not differ statistically between the control group and hypothyroid patients both before and after the therapy. The cardiovascular risk factors for systolic and diastolic blood pressure, HOMA-IR index, triglyceride, Apo B and ApoB/ApoA, homocysteine, $\beta-2$ microglobulin, and CIMT were found to be elevated in patients. Ox-LDL, cholesterol, homocysteine, and proteinuria concentrations were positively correlated with anti-Tg concentrations.

Conclusion: Serum visfatin concentrations were not associated with thyroid autoimmunity and atherosclerosis.

Keywords: Visfatin, autoimmune hypothyroidism, atherosclerosis 


\section{Öz}

Amaç: Visfatin/pre-B cell enhancement factor; insülin direnci, diyabet, dislipidemi, inflamasyon, otoimmun hastalıklar ve ateroskleroz patogeneziyle ilişkili adipoz dokudan salınan TNF-alfa ve IL-6 gibi inflamatuar sitokinlerin yapımını uyarır. Bu çalışmada amacımız otoimmün hipotiroidizmli hastalarda plazma visfatin düzeyi ve bunun tiroid otoimmünitesi ve ateroskleroz ile ilişkisini değerlendirmektir.

Gereç ve Yöntem: Çalışmamıza 35 yeni tanı almış Hashimoto hipotiroidili olgu (32 kadın/3 erkek, ort. yaş 43.8 \pm 9.6 ) ve 18 sağlıklı kontrol (17 kadın/1 erkek, ort. yaş 43.3 \pm 5.2$)$ dahil edildi. Tiroid hormon replasmanı öncesi ve sonrası antropometrik ölçümler, karotid intima-media kalınlığ (KIMK), serum anti-Tg, anti-TPO, hsCRP, homosistein, lipo(a), ApoA, ApoB1, $\beta$-2 mikroglobulin, insulin, glukoz, visfatin, IL6, TNF- $\alpha$, okside-LDL, lenfosit subgrupları ve lipid profile ölçümleri yapıldı. Serum visfatin konsantrasyonları ELİSA yöntemiyle çalışıldı.

Bulgular: Serum visfatin konsantrasyonları otoimmün hipotiroidizm grubu ile kontrol grubu arasında benzerdi $(6.29 \pm 1.63 \mathrm{ng} / \mathrm{ml}$ to $6.36 \pm 1.51 \mathrm{ng} / \mathrm{ml}, \mathrm{p}>0.05)$, tiroid otoimmünitesi ve ateroskleroz belirteçleriyle korelasyonu saptanmadı. Tedavi öncesi ve sonrası hipotiroidi hastalarının plazma visfatin, okside LDL, IL-6 ve TNF- $\alpha$ konsantrasyonları ile sağlıklı kontrol grubu arasında istatiksel farklılık görülmedi. Sistolik ve diyastolik kan basıncı, HOMA-IR, trigliserid, Apo B and ApoB/ApoA, homosistein, $\beta-2$ mikroglobulin, KIMKK gibi kardiyovasküler risk faktörleri hasta grubunda yüksek olarak bulundu. Okside-LDL, kolesterol, homosistein ve proteinuria konsantrasyonları anti-Tg ile pozitif korele idi.

Sonuç: Serum visfatin konsantrasyonları ile tiroid otoimmünitesi ve ateroskleroz arasında ilişki bulunmadı.

Anahtar Kelimeler: Visfatin, otoimmün hipotiroidi, ateroskleroz

\section{Introduction}

"Hashimoto's thyroiditis" is the most common cause of hypothyroidism. Loss of immune tolerance and the effect of antigen-producing cells cause autoreactive cells to invade the thyroid gland and induce apoptosis of thyrocytes [1].

Hypothyroidism increases the risk of cardiovascular disease [2]. Visfatin/pre-B cell enhancement factor, found in visceral adipose tissue, stimulates the growth of B cell precursors in the presence of IL-7 and stem cell factor. It is also found in activated lymphocytes, monocytes and neutrophils, bone marrow, skeletal muscles and the liver [3]. Visfatin is a cytokine induces the production of proinflammatory cytokines including IL-6, TNF-alfa and IL-1[4] and it was found to be elevated in sepsis, autoimmune disorders and in low-grade inflammation, i.e. atherosclerosis [5]. Visfatin concentrations were demonstrated to be increased in several autoimmune diseases such as rheumatoid arthritis, systemic lupus erythematosus, and psoriasis [6-8]. Both hypothyroidism and hyperthyroidism could affect serum visfatin concentrations however, the results are controversial [9].
In this study, we hypothesized that visfatin/pre-B cell enhancement factor as an adipocytokine released from visceral adipose tissue might provide a bridging function between thyroid autoimmunity and atherosclerosis in autoimmune hypothyroidism. Therefore, we aimed to evaluate plasma visfatin concentrations in patients with autoimmune hypothyroidism and its relationship with thyroid autoimmunity and atherosclerosis.

\section{Material and Method}

We enrolled 35 patients with newly diagnosed Hashimoto's thyroiditis ( 32 women $/ 3$ men, mean age $43.8 \pm 9.6$ years) and 18 healthy controls (17 women/1 men, mean age $43.3 \pm 5.2$ years) in the study. Ethics committee permission was obtained from Eskişehir Clinical Research Ethics Committee and informed consent was provided for all participants.

Hashimoto's thyroiditis was determined as having the high anti-Tg (> $115 \mathrm{IU} / \mathrm{ml})$ and/or anti-TPO (> $34 \mathrm{IU} / \mathrm{ml})$ values and heterogeneous thyroid parenchyma and reduction in echogenicity on thyroid ultrasonography. Subjects 
with endocrinologic disease (Diabetes mellitus, Cushing syndrome, Addison's disease, etc.), clinically obvious atherosclerotic vascular disease, hypertension, hepatic or renal dysfunction, infectious diseases, previous diagnosis of Hashimoto's disease and/or another thyroid disease who is on treatment, normal concentrations of thyroid autoantibodies diagnosed with autoimmune disease apart from Hashimoto's thyroiditis, drug use such as medications that disrupt efficacy of L-thyroxine treatment (cholestyramine, furosemide, coumadin, proton pump inhibitor, etc.), steroid or immunosuppressive treatment were excluded.

Height, weight, waist and hip circumference, systolic and diastolic blood pressures of all participants were measured. All patients right and left carotid intima-media thickness were determined using Toshiba SSA - 240 (Toshiba, Tokyo, Japan) ultrasound with $7.5 \mathrm{MHz}$ linear array transducer by the same radiologist in the radiology department. Venous blood samples were taken from an antecubital vein before and after treatment (at 8th week) after an 8-hour overnight fasting period. After blood samples were centrifuged at $4000 \mathrm{x}$ g for 5 minutes, the following tests were performed on the same day at Eskişehir Osmangazi University Faculty of Medicine Biochemistry laboratories, using Roche original kits on a Roche Modular autoanalyzer: serum TSH $(\mu \mathrm{IU} / \mathrm{ml})$, free T3 $(\mathrm{pg} / \mathrm{ml})$, free T4 $(\mathrm{ng} / \mathrm{ml})$, anti-Tg antibody, anti-TPO antibody, hsCRP (mg/L), homocysteine $(\mu \mathrm{mol} / \mathrm{L})$, lipid profile, lipo(a) $(\mathrm{mg} / \mathrm{dl})$, ApoA (mg/dl), ApoB1 (mg/dl), beta 2 microglobulin (ng/ $\mathrm{ml})$, insulin $(\mu \mathrm{U} / \mathrm{ml})$, and glucose $(\mathrm{mg} / \mathrm{dl})$. To evaluate visfatin ( $\mathrm{ng} / \mathrm{ml})$, IL-6 (pg/ml), TNF-alpha (pg/ml) and oxidized-LDL ( $\mathrm{ng} / \mathrm{ml}$ ) concentrations, serum samples were stored at $-80{ }^{\circ} \mathrm{C}$ until analysis. Fibrinogen was studied at ESOGU hematology laboratory using a Fibrinogen - C XL (HemosIL, USA) kit on an ACL TOP device, with lymphocyte subgroups (CD4, CD8, CD19, CD56) studied using Diaclone antibody on a Becton Dickinson FACS Calibur device in the same day blood samples were taken.

L-thyroxine treatment half an hour before breakfast was started to all cases newly diagnosed with hypothyroidism. During follow-up, patients were asked whether they regularly use the medication or use any medications that could affect treatment. After achievement of euthyroidism, blood samples were taken to check the same parameters evaluated before the beginning of therapy. HOMA-IR index developed by Matthews et al. was used (fasting blood sugar $(\mathrm{mg} / \mathrm{dl}) \mathrm{X}$ insülin $(\mu \mathrm{U} / \mathrm{ml}) / 405)$ for diagnosis of insulin resistance. HOMA index values above 2.7 are accepted as the presence of insulin resistance [10].

\section{Measurement of Serum Visfatin}

The concentration of Visfatin was measured using enzyme-linked immunosorbent assay (ELISA) method. Commercially available human Visfatin ELISA kit (Phoenix Pharmaceuticals, USA) was used. The procedure for the ELISA method was carried out according to the instructions provided by the manufacturer. The concentrations of Visfatin are presented as $\mathrm{ng} / \mathrm{ml}$.

\section{Statistical Analysis}

All statistical analysis was performed by using SPSS Version 13.0 (SPSS, Inc, Chicago, IL, USA). Data were expressed as a mean \pm standard deviation. Data with normal distribution before and after treatment were assessed by using the sample paired t-test, while data with nonnormal distribution were assessed by the Wilcoxon t-test. Correlations were analyzed with Pearson test. P values of less than 0.05 were accepted as statistically significant.

\section{Results}

Demographics and laboratory values of patients and control group were shown in Table 1. Mean age and BMI were similar between groups $(p>0.05)$. ApoB, ApoB/ApoA1, homocysteine and beta 2-microglobulin concentrations and mean CIMT was significantly higher in the patient group before treatment when compared with healthy controls $(p<0.05)$ (Table 1$)$. Mean serum visfatin concentrations were similar between autoimmune hypothyroidism group and control group $(6.29 \pm 1.63 \mathrm{ng} /$ $\mathrm{ml}$ to $6.36 \pm 1.51 \mathrm{ng} / \mathrm{ml}, \mathrm{p}>0.05$ ) and it was not correlated with thyroid autoimmunity and atherosclerosis markers. Serum IL-6, TNF- $\alpha$ and oxidized-LDL concentrations measured before treatment in hypothyroid patients were compared with control group and statistically significant difference was not found $(\mathrm{p}>0.05)$ (Table 2). 
Table 1: Demographics and laboratory values of patients and control group

\begin{tabular}{|c|c|c|c|}
\hline & $\begin{array}{l}\text { Patients group } \\
\text { (n:35) }\end{array}$ & $\begin{array}{c}\text { Control } \\
\text { group (n:18) }\end{array}$ & $\mathbf{P}$ \\
\hline Age (year) & $43.85 \pm 9.68$ & $43.38 \pm 5.27$ & 0.850 \\
\hline BMI (kg/m2) & $28 \pm 5$ & $25 \pm 4$ & 0.057 \\
\hline SBP (mmHg) & $120.14 \pm 17.42$ & $107.22 \pm 8.26$ & 0.005 \\
\hline DBP (mmHg) & $77.85 \pm 13.24$ & $67.77 \pm 10.60$ & 0.007 \\
\hline FT3 (pg/ml) & $3.03 \pm 0.90$ & $3.38 \pm 0.50$ & $<0.001$ \\
\hline FT4 (ng/dl) & $0.77 \pm 0.24$ & $1.01 \pm 0.12$ & $<0.001$ \\
\hline TSH ( $\mu \mathrm{IU} / \mathrm{ml})$ & $30.41 \pm 44.3$ & $1.72 \pm 0.83$ & $<0.001$ \\
\hline FPG (mg/dl) & $91.85 \pm 11.07$ & $82.05 \pm 9.63$ & 0.002 \\
\hline Insülin ( $\boldsymbol{\mu U} / \mathbf{m l})$ & $7.06 \pm 7.87$ & $3.20 \pm 1.31$ & 0.045 \\
\hline HOMA-IR & $1.52 \pm 1.73$ & $0.62 \pm 0.32$ & 0.034 \\
\hline TG (mg/dl) & $131.91 \pm 57.58$ & $96.38 \pm 39.47$ & 0.023 \\
\hline HDL-C (mg/dl) & $49.80 \pm 10.63$ & $53.72 \pm 11.53$ & 0.222 \\
\hline LDL-C (mg/dl) & $125.60 \pm 36.99$ & $121.94 \pm 26.75$ & 0.712 \\
\hline $\begin{array}{l}\text { Total Cholesterol } \\
\text { (mg/dl) }\end{array}$ & $199.09 \pm 49.39$ & $195.39 \pm 31.83$ & 0.775 \\
\hline ApoB (mg/dl) & $94.20 \pm 23.36$ & $84.70 \pm 16.46$ & 0.023 \\
\hline ApoB/ApoA1 & $0.61 \pm 0.18$ & $0.50 \pm 0.11$ & 0.027 \\
\hline Mean CIMT & $0.72 \pm 0.22$ & $0.58 \pm 0.02$ & 0.015 \\
\hline $\begin{array}{l}\text { Homocysteine } \\
(\mu \mathrm{mol} / \mathrm{l})\end{array}$ & $9.99 \pm 3.63$ & $8.27 \pm 3.44$ & 0.009 \\
\hline $\begin{array}{l}\text { Beta-2 } \\
\text { microglobulin } \\
\text { (ng/L) }\end{array}$ & $1503.71 \pm 510.75$ & $1486.83 \pm 282.23$ & 0.029 \\
\hline
\end{tabular}

Table 2: The comparison of adipocytokines and oxidisedLDL cholesterol concentrations between groups

\begin{tabular}{|l|c|c|c|}
\hline & $\begin{array}{c}\text { Patients } \\
\text { Group }(\mathbf{n = 3 5})\end{array}$ & $\begin{array}{c}\text { Control } \\
\text { Group (n=18) }\end{array}$ & P \\
\hline Visfatin (ng/ml) & $6.29 \pm 1.63$ & $6.36 \pm 1.51$ & $\mathrm{P}=0.600$ \\
\hline Ox LDL (ng/ml) & $111.25 \pm 156.16$ & $83.83 \pm 68.38$ & $\mathrm{P}=0.077$ \\
\hline TNF- $\boldsymbol{\alpha}(\mathbf{p g} / \mathbf{m l})$ & $5.24 \pm 3.08$ & $4.43 \pm 1.78$ & $\mathrm{P}=0.225$ \\
\hline IL-6 (pg/ml) & $4.32 \pm 2.65$ & $3.92 \pm 1.12$ & $\mathrm{P}=0.199$ \\
\hline
\end{tabular}

Comparisons of plasma glucose, insülin, lipid parameters, homocysteine and lipoprotein concentrations before and after treatment were shown in Table 3. ApoB, homocysteine and ApoB/ApoA1 concentrations before treatment were significantly higher than values measured after treatment $(\mathrm{p}<0.05)$ (Table 3$)$. Serum visfatin, TNF- $\alpha$, IL-6, and oxidized-LDL were similar between before and after treatment $(\mathrm{p}>0.05)$ (Table-4).
Table 3: Comparisons of plasma glucose, insülin, lipid parameters, homocysteine and lipoprotein concentrations before and after treatment

\begin{tabular}{|c|c|c|c|}
\hline & $\begin{array}{c}\text { Before } \\
\text { Treatment } \\
(\mathbf{n}=35)\end{array}$ & $\begin{array}{l}\text { After Treat- } \\
\text { ment }(n=35)\end{array}$ & $\mathbf{P}$ \\
\hline FT3 (pg/ml) & $3.03 \pm 0.90$ & $3.56 \pm 0.49$ & $<0.001$ \\
\hline FT4 (ng/dl) & $0.77 \pm 0.24$ & $1.32 \pm 0.29$ & $<0.001$ \\
\hline TSH $(\mu \mathrm{IU} / \mathrm{ml})$ & $30.41 \pm 44.3$ & $0.78 \pm 0.59$ & $<0.001$ \\
\hline FPG (mg/dl) & $91.8 \pm 11 \mathrm{mg} / \mathrm{dl}$ & $90,4 \pm 10.8$ & 0.440 \\
\hline Insülin $(\mu \mathrm{U} / \mathrm{ml})$ & $7.0 \pm 7.8$ & & 0.069 \\
\hline HOMA-IR & $1.5 \pm 1.7$ & & 0.125 \\
\hline $\begin{array}{l}\text { Total cholesterol } \\
\text { (mg/dl) }\end{array}$ & $199.08 \pm 49.39$ & $190.71 \pm 35.17$ & 0.249 \\
\hline LDL-C (mg/dl) & $125.60 \pm 36.99$ & 118.00 & 0.170 \\
\hline HDL-C (mg/dl) & $49.80 \pm 10.63$ & $48.00 \pm 10.98$ & 0.196 \\
\hline TG (mg/dl) & $131.91 \pm 57.58$ & $120.60 \pm 44.70$ & 0.087 \\
\hline ApoB (mg/dl) & $94.20 \pm 23.36$ & $87.37 \pm 21.60$ & 0.023 \\
\hline ApoB/ApoA1 & $0.61 \pm 0.18$ & $0.56 \pm 0.11$ & 0.006 \\
\hline $\begin{array}{l}\text { Homocysteine } \\
(\mu \mathrm{mol} / \mathrm{l})\end{array}$ & $9.99 \pm 3.63$ & $8.54 \pm 2.79$ & 0.009 \\
\hline
\end{tabular}

Abbreviations: HOMA-IR: Homeostasis model assessment, TSH: Thyroid stimulating hormone, FT4: Free thyroxine, FT3: free T3, FPG: Fasting plasma glucose, LDL-C: low-density lipoprotein cholesterol, HDL-C: high-density lipoprotein cholesterol, TG: triglyceride, ApoB: apolipoprotein B, ApoA1: Apolipoprotein A1

Table 4: Comparisons of adipocytokines and oxidisedLDL cholesterol concentrations before and after treatment

\begin{tabular}{|l|c|c|c|}
\hline & $\begin{array}{c}\text { Before Treatment } \\
(\mathbf{n = 3 5})\end{array}$ & $\begin{array}{c}\text { After Treat- } \\
\text { ment } \mathbf{( n = 3 5 )}\end{array}$ & P \\
\hline Visfatin (ng/ml) & $6.29 \pm 1.63$ & $6.08 \pm 1.85$ & 0.600 \\
\hline Ox LDL (ng/ml) & $111.25 \pm 156.16$ & $143.53 \pm 251.95$ & 0.077 \\
\hline TNF- $\boldsymbol{\alpha}(\mathbf{p g} / \mathbf{m l})$ & $5.24 \pm 3.08$ & $7.10 \pm 7.98$ & 0.225 \\
\hline IL-6 (pg/ml) & $4.32 \pm 2.65$ & $17.86 \pm 6.97$ & 0.199 \\
\hline
\end{tabular}

Separate comparisons of lymphocyte subgroups in the patient group before treatment were similar with the control group and they were not affected by levothyroxine treatment (Table 5).

Table 5: The comparison of lymphocyte subgroups before and after treatment with control group

\begin{tabular}{|c|c|c|c|}
$\begin{array}{c}\text { Before } \\
\text { Treatment } \\
(\mathbf{n}=\mathbf{3 5})\end{array}$ & $\begin{array}{c}\text { After } \\
\text { Treatment } \\
(\mathbf{n}=\mathbf{3 5})\end{array}$ & $\begin{array}{c}\text { Control } \\
\text { group } \\
(\mathbf{n}: 18)\end{array}$ & $\mathbf{P} *$ \\
\hline
\end{tabular}

\begin{tabular}{|l|l|l|l|l|l} 
CD4+ (\%) & $43.07 \pm 5.90$ & $43.60 \pm 6.09$ & $45.89 \pm 8.72$ & $>0.05$ \\
\hline
\end{tabular} \begin{tabular}{|l|l|l|l|l|l}
\hline CD8+ (\%) & $26.67 \pm 7.69$ & $26.70 \pm 8.03$ & $25.01 \pm 5.17$ & $>0.05$ \\
\hline
\end{tabular} \begin{tabular}{|l|l|l|l|l|l|}
\hline CD19+ (\%) & $10.47 \pm 3.51$ & $9.97 \pm 2.96$ & $10.53 \pm 3.09$ & $>0.05$ \\
\hline
\end{tabular} \begin{tabular}{|l|l|l|l|l|l|}
\hline CD56+ (\%) & $13.20 \pm 6.28$ & $13.11 \pm 6.52$ & $13.72 \pm 6.29$ & $>0.05$ \\
\hline
\end{tabular} \begin{tabular}{|l|l|l|l|l|l|}
\hline CD4+/CD8+ & $1.76 \pm 0.72$ & $1.74 \pm 0.62$ & $1.90 \pm 0.67$ & $>0.05$ \\
\hline
\end{tabular} *Both for Before treatment versus control group and before treatment versus after treatment 
Anti-thyroglobulin antibody(anti-Tg) concentrations were positively correlated with Ox-LDL $(\mathrm{r}=0.373, \mathrm{p}=0.027)$, total cholesterol $(\mathrm{r}=0.365, \mathrm{p}=0.031)$, HDL-C $(\mathrm{r}=0.347$, $\mathrm{p}=0.041)$, homocysteine $(\mathrm{r}=0.390, \mathrm{p}=0.021)$.

\section{Discussion}

A variety of studies has evaluated the relationship between visfatin and thyroid dysfunction. Caixas et al. [11] investigated plasma visfatin concentrations in hyperthyroidism and hypothyroidism both before and after treatment. The patients with hyperthyroidism had higher visfatin concentrations which increased after treatment. Hypothyroid patients had higher visfatin concentrations, which further increased after treatment regardless of changes in anthropometric and insulin resistance parameters. They could not find a correlation between visfatin and any other parameters. Ozkaya et al. [12] also evaluated the serum visfatin concentrations hypothyroidism and hyperthyroidism before and after treatment. The patients with hyperthyroidism had lower visfatin concentrations compared with the hypothyroid group and controls. A significant degree of decrease in plasma visfatin concentrations was observed following treatment of patients with hypothyroidism. In patients with hyperthyroidism, an increase in plasma visfatin concentrations was observed with anti-thyroid treatment. A positive correlation between visfatin and TSH concentrations and a negative correlation between visfatin concentrations and fT3 and fT4 values were observed. Han et al. [13] examined the regulation of visfatin by thyroid hormones both in vivo and in-vitro and they found both hyperthyroidism and hyperthyroidism were associated with elevated visfatin concentrations. Sawicka-Gutaj et al. [14] investigated whether coexisting autoimmune inflammation in hypothyroidism could have an effect on serum visfatin concentrations or not. They demonstrated that visfatin serum concentration in hypothyroid patients is associated with both autoimmunity and free thyroid hormones level. In our study, serum visfatin concentrations were similar between autoimmune hypothyroidism group and control group and, it was not correlated with thyroid autoimmunity and atherosclerosis markers. We also could not find a difference in visfatin concentrations by levothyroxine treatment. The idea of a possible involvement of visfatin in the pathogenesis of autoimmune thyroiditis was not suggested by our study. As the measurement of these values was completed 6-8 weeks after the beginning of treatment, we still do not know whether the visfatin concentrations are affected by treatment in the long term or not. Together with this, our results showed that visfatin concentrations were not affected by the hypothyroid situation, and as it is secreted by adipose tissue, it may have similar concentrations to healthy controls with similar BMI.

In many studies, clinical or subclinical hypothyroidism has been demonstrated as a risk factor for atherosclerosis and cardiovascular disease [15]. Increased concentrations of LDL-C, VLDL-C, HDL-C, ApoB and lipoprotein (a) are seen in patients with hypothyroidism and thyroid hormone replacement provides a decrease in plasma cholesterols, ApoB, homocysteine and ApoB/ApoA1 concentrations [16]. Studies have shown plasma visfatin concentrations are associated with BMI, diabetes mellitus, metabolic syndrome and coronary artery disease [1720]. Dahl et al. [4] stated that visfatin may have a direct role in atherosclerosis and plaque destabilization. In our study, ApoB, ApoB/ApoA1, homocysteine and beta 2-microglobulin concentrations and mean CIMT were significantly higher in the patient group before treatment. ApoB, homocysteine and ApoB/ApoA1 concentrations were decreased by levothyroxine treatment. LDL-C, total cholesterol, TG concentrations were higher in the patient group before treatment. Although there is a trend towards a decrease in LDL-C, total cholesterol, TG concentrations by levothyroxine treatment, these concentrations were statistically not affected by levothyroxine treatment. These findings are consistent with the literature.

A positive correlation was found between anti-TG antibody and ox-LDL, cholesterol, homocysteine, and proteinuria. Based on these findings mainly non-traditional CVD risk factors are increased in hypothyroidism linked to Hashimoto's thyroiditis, accompanied by an increase in the atherosclerosis finding of CIMT, leading to the consideration that in anti-TG antibodies may have a bridging function between autoimmunity and atherosclerosis. 
In hypothyroidism, another risk factor for CVD has increased the prevalence of obesity. The increased adipose tissue could lead to a release of adipocytokines such as leptin, adiponectin, resistin, visfatin, TNF- $\alpha$, and IL-6 [21]. Serum visfatin concentrations were shown to be increased in several autoimmune diseases such as rheumatoid arthritis or inflammatory bowel disease [22]. Visfatin stimulates the production of proinflammatory cytokines such as IL-6 and tumor necrosis factor- $\alpha$ which were higher in patients with autoimmune thyroid dysfunction [23,24]. IL-6 can stimulate the expression of visfatin [25]. Moreover, it can be postulated that visfatin release from adipose tissue might be influenced directly or indirectly by proinflammatory cytokines which have been implicated in thyroid dysfunction. Oxidized-LDL is a marker with a significant role in the formation of atherosclerotic plaque and pathogenesis of atherosclerosis. Many studies have found that ox-LDL concentrations are high in individuals with coronary artery disease [26]. However, serum visfatin, IL-6, TNF- $\alpha$ and oxidized-LDL concentrations were similar in patients with hypothyroidism and control group in our study. Additionally, serum TNF- $\alpha$, IL- 6 , and oxidizedLDL were not affected by levothyroxine treatment. These findings could be explained by similar BMI in patients and control groups, many of our patients were not obese.

The mechanisms of the relationship between visfatin and insulin resistance are not clear. Studies have not found a correlation between visfatin and HOMA-IR [27,28]. In our study, there was no correlation between serum visfatin concentrations and HOMA-IR index. Carotid artery intima-media thickness (CIMT) is shown to have a clear correlation with all risk factors for atherosclerosis [29]. In our study, CIMT was higher in patients with hypothyroidism however, we did not find a correlation between visfatin concentrations and CIMT.

Atherosclerotic human and animal studies demonstrated autoantibodies against ox-LDL in circulation and immunoglobulins in atherosclerotic lesions lead to the consideration of B-lymphocytes might play a role in the pathogenesis of atherosclerosis [30]. Since subgroups of T-lymphocytes are related to autoimmune events, there are changes in T-lymphocyte subgroups in these events. There are contradictory data related to an association between numbers of T-lymphocyte subgroups found in peripheral blood and autoimmune diseases. A study by Covas et al. [31] of 44 autoimmune thyroid disease patients found a strong effect of functional concentrations of the thyroid hormones on CD3, CD4 and CD8 values which had a negative correlation with fT4 and positive correlation with TSH. The results of the same study observed that CD4/ CD8 ratio was decreased in hypothyroidism related to Hashimoto's thyroiditis and increased in hyperthyroidism related to Graves' disease. Moschen et al. [32] showed that recombinant visfatin activated human leukocytes and stimulated cytokine production and it increased the surface expression of costimulatory molecules. In our study, we did not find a difference between lymphocyte subgroups evaluated before and after treatment.

A relatively small sample size with a cross-sectional design is the major limitation of our study.

\section{Conclusion}

Serum visfatin concentrations were not associated with thyroid autoimmunity and atherosclerosis. On the other hand, non-traditional CVD risk factors are higher in hypothyroid patients with Hashimoto's thyroiditis accompanied by an increase in CIMT measurement and, the anti-Tg antibody might be a bridge between autoimmunity and atherosclerosis. Our findings did not suggest a pathophysiological relationship between thyroid autoimmunity and visfatin which was shown by previous studies. Extensive studies covering larger populations are needed to enlighten the relationship between visfatin and thyroid autoimmunity.

\section{Declaration of conflicting interests}

The authors declared no conflicts of interest with respect to the authorship and/or publication of this article.

Funding: This study was supported by Scientific Research Projects of Eskişehir Osmangazi University (No: 200911001)

\section{References}

1. Pearce EN, Farwell AP, Braverman LE. Thyroiditis. New England J Med 2003; 348: 2646-55. 
2. Nyirenda MJ, Clark DN, Finlayson AR, et al. Thyroid disease and increased cardiovascular risk. Thyroid 2005; 15:718-24.

3. Luk T, Malam Z, Marshall JC. Pre-B cell colony-enhancing factor $(\mathrm{PBEF}) /$ visfatin: a novel mediator of innate immunity. J Leukoc Biol 2006; 83:10-3.

4. Dahl TB, Yndestad A, Skjelland M, et al. Increased expression of visfatin in macrophages of human unstable carotid and coronary atherosclerosis: possible role in inflammation and plaque destabilization. Circulation 2007; 115: 972-80.

5. Dahl TB, Holm S, Aukrust P, Halvorsen B. Visfatin/NAMPT: a multifaceted molecule with diverse roles in physiology and pathophysiology. Annu Rev Nutr 2012; 32: 229-43.

6. Brentano F, Schorr O, Ospelt J, et al. Pre-B cell colony-enhancing factor/visfatin, a new marker of inflammation in rheumatoid arthritis with proinflammatory and matrix-degrading activities. Arthritis \& Rheumatism 2007; 56: 2829-39.

7. Chung CP, Long AG, Solusetal JF. Adipocytokines in systemic lupus erythematosus: relationship to inflammation, insulin resistance and coronary atherosclerosis. Lupus 2009; 18: 799-806.

8. Ismail S, Mohamed SA. Serum concentrations of visfatin and omentin-1 in patients with psoriasis and their relation to disease severity. British J Dermatol 2012; 167: 436-9.

9. Cinar N, Gurlek A. Association between novel adipocytokines adiponectin, vaspin, visfatin, and thyroid: an experimental and clinical update. Endocrine Connections 2013; 2: 30-8.

10. Matthews DR, Hosker JP, Rudenski AS, et al. Homeostasis model assessment: insulin resistance and beta-cell function from fasting plasma glucose and insulin concentrations in man. Diabetologia $1985 ; 28: 412-9$.

11. Caixàs A, Tirado R, Vendrell J, Gallart L, Megía A. Plasma visfatin concentrations increase in both hyper and hypothyroid subjects after normalization of thyroid function and are not related to insulin resistance, anthropometric or inflammatory parameters. Clin Endocrinol (Oxf) 2009; 71: 733-8.
12. Özkaya M, Sahin M, Cakal E, et al. Visfatin plasma concentrations in patients with hyperthyroidism and hypothyroidism before and after control of thyroid function. J Endocrinol İnvest 2009; 32: 435-9.

13. Han J, Zhang TO, Xiao WH, Chang CQ, Ai H. Up-regulation of visfatin expression in subjects with hyperthyroidism and hypothyroidism is partially relevant to a nonlinear regulation mechanism between visfatin and tri-iodothyronine with various concentrations. Chinese Med J 2012; 125: 874-81.

14. Sawicka-Gutaj N, Zybek-Kocik A, Klimowicz A, et al. Circulating Visfatin in Hypothyroidism Is Associated with Free Thyroid Hormones and Antithyroperoxidase Antibodies. Int J Endocrinol 2016: 7402469 .

15. Nyirenda MJ, Clark DN, Finlayson AR, et al. Thyroid disease and increased cardiovascular risk. Thyroid 2005; 15: 718-4.

16. Efstathiadou Z, Bitsis S, Milionis HJ, et al. Lipid profile in subclinical hypothyroidism: is L-thyroxine substitution beneficial? Eur J Endocrinol 2001; 145: 705-10.

17. Zhong M, Tan HW, Gong HP, Wang SF, et al. Increased serum visfatin in patients with metabolic syndrome and carotid atherosclerosis. Clin Endocrinol (Oxf) 2008; 69: 878-8432.

18. Weyer C, Funahashi T, Tanaka S, et al. Hypoadiponectinemia in obesity and type 2 diabetes: close association with insulin resistance and hyperinsulinemia. J Clin Endocrinol Metab 2001; 86: $1930-35$

19. Zahorska-Markiewicz B, Olszanecka-Glinianowicz M, Janowska $\mathrm{J}$, et al. Serum concentration of visfatin in obese women. Metabolism 2007;56 :1131-4.

20. Liu SW, Qiao SB, Yuan J, Liu DQ. Association of plasma visfatin levels with inflammation, atherosclerosis and acute coronary syndromes (ACS) in humans. Clin Endocrinol (Oxf) 2009; 71: 202-7.

21. Chen MP, Chung FM, Chang DM, et al. Elevated plasma level of visfatin/pre-B cell colony enhancing factor in patients with type 2 diabetes mellitus. J Clin Endocrinol Metab 2006; 91: 295-9. 
22. Moschen AR, Kaser A, Enrich B, et al. Visfatin, an adipocytokine with proinflammatory and immunomodulating properties. J Immunol 2007;178: 1748-58.

23. Han J, Zhang TO, Xiao WH, Chang CQ, Ai H. Up-regulation of visfatin expression in subjects with hyperthyroidism and hypothyroidism is partially relevant to a nonlinear regulation mechanism between visfatin and tri-iodothyronine with various concentrations. Chinese Med J 2012; 125: 874-81.

24. Celik I, Akalin S, Erbas T. Serum levels of interleukin 6 and tumor necrosis factor-a in hyperthyroid patients before and after propylthiouracil treatment. Eur J Endocrinol 1995;132: 668-72.

25. Salvi M, Pedrazzoni M, Girasole G, et al. Serum concentrations of proinflammatory cytokines in Graves' disease: effect of treatment, thyroid function, ophthalmopathy and cigarette smoking. Eur J Endocrinol 2000; 143: 197-202.

26. Kita T, Kume N, Minami, et al. Role of oxidized LDL in atherosclerosis. Ann N Y Acad Sci 2001;947: 199-205.

27. Berndt J, Kloting N. Plasma visfatin concentrations and fat depotspecific mRNA expression in humans. Diabetes 2005;54: 2.

28. Dogru T, Sonmez A, Tasci I, et al. Plasma visfatin levels in patients with newly diagnosed and untreated type 2 diabetes mellitus and impaired tolerance. Diabetes Res Clin Pract 2007,76: 24-9.
29. O’Leary DH, Pollak JF. Intima-media thickness: a tool for atherosclerosis imaging and event prediction. Am J Cardiol 2002;90:18-21.

30. Hulthe J, Fagerberg B. Circulating oxidized LDL is associated with subclinical atherosclerosis development and inflammatory cytokines (AIR Study). Arterioscler Thromb Vasc Biol 2002;22: 1162-7.

31. Covas MI, Esquerda A, García-Rico A, Mahy N. Peripheral blood T-lymphocyte subsets in autoimmune thyroid disease. J Investig Allergol Clin Immunol 1992;2:131-5.

32. A. R. Moschen, A.Kaser, B.Enrichetal, et al. Visfatin, an adipocytokine with proinflammatory and immunomodulating properties. J Immunol 2007; 178: 1748-58.

Corresponding Author: Bekir Ucan, Dışkapı Yildirim Beyazıt Training and Research Hospital, Ziraat Mahallesi, Şehit Ömer Halisdemir Cad, 06110, Dışkapı, Altındağ, Ankara E-mail: uzm.dr.bekir@hotmail.com 